\title{
Peculiarities of the EEU countries interaction in pharmaceutical value chains in pandemic period
}

\author{
Elena Frolova $^{1, *}$, Irina Turgel $^{1}$, Alexander Ishukov ${ }^{1,2}$, and Zulparuza Abdurahmanova ${ }^{3}$ \\ ${ }^{1}$ Ural Federal University named after the First President of Russia B.N. Yeltsin, Mira Str., 19, 620002 \\ Ekaterinburg, Russia \\ ${ }^{2}$ Institute of Economics, Ural Branch of the Russian Academy of Sciences, Moskovskaya Str., 29, \\ 620014 Ekaterinburg, Russia \\ ${ }^{3}$ Karaganda University of Kazpotrebsouz, Academic Str., 9, 100009 Karaganda, Kazakhstan
}

\begin{abstract}
Taking into account that new trends are emerging in the field of international economic integration in pandemic world the authors aimed to study the role of the country's participation in global value chains (GVCs) in the development of the Eurasian Economic Union (EEU or EAEU) national pharmaceutical industry. The article reveals the contradictory essence of modern concepts of interaction between the countries of integration associations and GVCs including its specificity for the EEU. An analysis of the pharmaceutical industry in EEU before and in the pandemic is carried out, and the features of such interaction are revealed in more detail in Kazakhstan case. The results showed the presence of low volumes of pharmaceutical products in EEU intraregional trade and minimum presence in GVCs. The hypothesis was partially confirmed that the countries localized the GVC "production" stage on their territory received gain as the increase in domestic production in pandemic period, despite the fact that this stage corresponds to low added value. The novelty is in the development of a reproductive approach to the study of integration groups. Recommendations are given to increase the share of economic entities of the EEU countries in the process of forming regional value chains.
\end{abstract}

\section{Introduction}

In the last decade, the structure of the world economy has been determined by the activity of added value chains (VC). Depending on their geographic coverage, they are called global (GVC) or regional (as a rule, in the regional integration associations). Many countries are involved in $\mathrm{VC}$, therefore, there are several models for the national actors participation in them, depending on the priority of the goals, as follows $[1,2,3]$ : from one side, the GVCtheory mentions that a country must locate on its territory the links with the maximum added value, from the other side, in the pandemic period, when export is restricted due to quarantine, countries that have localized on their territory the "production" link, which

\footnotetext{
*Corresponding author: frol-uved@yandex.ru
} 
corresponds to the minimum added value, win (because, in this case the final pharmaceuticals are produced in their own country and do not need to be imported).

The main GVCs operate within the framework of TNCs, whose headquarters are located in the USA, Europe. For the EEU (as EAEU in different some sources) countries, there is a rather acute problem of increasing their role in the process of forming $\mathrm{VC}$ in the world [1]. First of all, it is necessary to study the internal factors that are holding back the development of the EEU through the prism of $\mathrm{VC}$, including the low volume of intraregional trade, insufficient use of imported components for GVC (today, the final pharmaceutical product produced on their basis is sent not for export, but for domestic consumption) $[2,4]$.

Countries, including EEU ones, are particularly interested in non-resource industries, including the pharmaceutical. Despite the fact that the share of the EEU in the world market of pharmaceuticals is only $2.6 \%$, but an increase in trade turnover in mutual trade of the union countries, a decrease volumes of imports from non-member countries are evidence of the sustainable development of the EEU pharmaceutical industry [6]. However, modern pharmaceuticals production is a complex process: to develop an effective pharmaceutical product, huge investment and scientific resources are needed. Nevertheless, scientists name the main priority in the development of networks as the intensification of supplies with the neighboring regions, the search for mutually beneficial cooperation with leading companies located in the same region. This enhances the relevance of the study in terms of searching for new opportunities for the formation of pharmaceutical GVCs in groups of countries, i.e. regional integration associations.

Despite the fact that the number of publications devoted to the interaction between the EEU and the GVC has recently increased [1,2,3], some of them reflect specific issues only, for example, the formation of the concept of a roadmap for the development of a single pharmaceutical market of the EEU in the context of pharmaceuticals safety, import substitution $[4,5]$. But the new characteristics of the world economic environment require an in-depth industry study of this problem using GVC analysis, i.e. through the prism of international reproduction process.

Therefore, the authors made an attempt to identify the significance and features that make a specific model of participation of the EEU countries in global (regional) pharmaceutical value chains, as well as their role in the development of the national pharmaceutical industry. Since the material on the leading countries is informative, the study was carried out on Russian and Kazakh markets.

\section{Theoretical aspects of the value chains functioning of within the EEU framework}

Based on the analysis of academic literature we can formulate some of the most important conceptual statements.

First. GVC is an international reproduction process with some features: the process is fragmented strongly (from raw materials to the final product), its stages are located in the territories of several countries, trade of components is dominated within its frame $[1,2,3]$. According to the opinion of T. Meshkova, E. Moiseichev [3], G, Grereffy [7] it is very important also to underline that stages have different level of added value (in pharmaceutical industry the links with the maximum level of added value are R\&D and the brand). Depending on the geographic coverage, they are global (GVC) or regional (they operate within a region, a regional integration association, or "when most of the added value of the AVC is created in regional blocks") [4, p. 76]. 
In the case of the essence of GVCs there is practically no disagreement among scientists, but as for using them for the national economy development there are some models $[1,4,7]$ :

- One group of scientists, primarily Western, promotes a monopolar configuration of the world economy: supranational interests dominate in it, links of the chain are recommended for localization, along which the country has competitive advantages; for developing countries, this can lead to de-industrialization, and for developed countries, the placement of links with a high level of added value on their territory (R\&D, brand management);

- Another group, primarily Russian, proposes a model that is aimed at developing the real sector of the national economy: national interests dominate in it, participation in GVCs (including through localization) is recommended only if the state is able to protect the national industry from dependence on external factors (on terms of cooperation).

Despite the possible risks of being in a GVC (for example, transformation the country into a "global" factory with bad ecological environment, etc.), regional value chains (if used skillfully) promise great benefits. Since the leading GVCs operate within TNCs (mainly through a joint-stock with foreign direct investment or contract form), these benefits are well known: access to new technologies, new markets, etc. But whether the GVC participants actually receive these benefits is a big question to be investigated. For example, V. V. Perskaya [1] and I. A. Manuilov [2] emphasize the importance of preserving and dominating national priorities in the field of economic integration when involved in GVCs, especially for the EEU.

The second provision concerns the essence of such concepts as "participation in the GVC", "presence in the GVC", "introducing GVC onto the territory of the EEU countries" which characterize the involvement in the global production fragmentation process. On the one hand, researchers distinguish between "forward participation" and "backward participation", while GVC analysis distinguishes the national and international parts of the value added within the chain $[2,3]$. On the other hand, the form of "introducing GVCs" into the territory of countries is the localization of GVC links, i.e. location of factories, assembly shops, scientific laboratories, decision-making centers, etc. on the territory of the country. At the same time, the chain is looking for favorable conditions for the localization of its links, for example, the presence in the territory of a set of factors that form the low cost of transactions, including competitive local national structural units, infrastructure for effective business communication and logistics, etc., this is the case of creating a stimulating environment for GVCs $[1,2,7]$. And the national economy, in turn, should get its own benefits: jobs, FDI, joint development of high-tech links. The EEU countries are capable, in cooperation with each other, to form such conditions on mutually beneficial base. We want to note one more contradiction also:

- On the one hand, stages with high added value are subject to localization in order to increase the national part of the world added value (for the pharmaceutical chain, this is R\&D link, which is located mainly in the developed countries);

- On the other hand, the developed countries (including USA and China), localize on their territory the "production" stage with low added value in order to avoid the risks of international trade and solving economic problems.

In other words, when choosing a form of participation in GVCs, it cannot be guided by one principle only - the placement of links with high added value on the territory of their country. The interests of TNCs, within the GVCs framework, should be balanced by the solution of the national development tasks (jobs for reduction unemployment).

Third. Some factors ensure the successful development for the countries of integrations through the tool of GVC: 
- A high level of reproductive openness, measured by the "percentage of the sum of the country's exports and imports to the volume of its GDP" [1, p. 30], which shows the degree of national economy involvement into the world ties system;

- Significant volume of intraregional trade, because of the intensive trade in components within GVCs [2, 4];

- Effective regional trade agreements (RTA) in the context of foreign trade regulation: since within the framework of the GVC, components are traded, and within the framework of integration associations, regional trade agreements are in force, then RTA intensifies trade in component (reduction of customs duties, non-tariff barriers, etc.) [2];

- Favorable business environment: in addition to harmonizing standards, an infrastructure is needed to enhance mutual trade, namely a developed customs and transport infrastructure, the pandemic has raised the issue of digital platforms.

All of the above reveals the essence of the reproductive approach to the study of integration associations, while the literature focuses on the institutional component.

\section{Research objective and methodology}

In order to study and assess the interaction of regional VCs and the integrations (incl. EEU) (this is the research goal), it is necessary to use such indicators as the volume of intraregional trade as an indicator of the development of GVCs, the number of leading companies for cooperation, the level of manageability of the introduced GVCs (through a share in the authorized capital), specialization of the country, quality of the business environment. To achieve the goal, the following tasks were set: to identify the presence and features of regional pharmaceutical VC operating in the EEU countries, to compare the results of the development of the pharmaceutical industry before and in the pandemic (using the example of the leading states) based on case study and GVC-analysis. GVCanalysis means an analysis throw the prism of the stages of GVCs. The study was carried out in accordance with the following author's algorithm.

Stage 1. Analysis of the main indicators of the state and dynamics of development of the pharmaceutical market of the EEU member states in order to identify the volumes of trade in pharmaceutical products in the EEU before and in a pandemic, as well as the volumes of mutual (intraregional) trade in pharmaceuticals as an indicator of the development of GVCs, the ratio with the volume of trade with non-member countries, as well as assessing the attractiveness of the business environment for the introduction of pharmaceutical VC to the territory of the EEU countries.

Stage 2. Analysis of the pharmaceutical industry and the domestic market in each of the participating countries (the result for the leading country is also informative) to identify features and development trends.

Step 2.1. Compilation of the characteristics of the pharmaceutical industry and the pharmaceutical market (using the example of one of the leading countries) before the pandemic and during the pandemic according to such indicators as: the total volume of production and trade of pharmaceutical products, the rate of their changes, the dynamics of export-import volumes, as well as the identification of national industry characteristics and business -environments.

Step 2.2. GVC-analysis of the country's pharmaceuticals, i.e. analysis through the prism of the stages of pharmaceutical VC, including the identification of localization features of the "production" link.

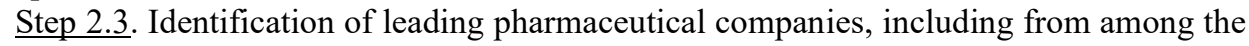
EEU member states acting as global or regional VCs, with the localization of their links in the selected country. The purpose of the stage is to identify the presence of leading 
companies for cooperation, as well as the level of their manageability (through the national share in the authorized capital).

Step 2.4. Revealing the form of interaction between economic entities of leading world or regional pharmaceutical companies with the localization of stages in the selected country. The goal is to test the hypothesis of introducing pharmaceutical GVCs into the territory of the EEU countries, identify best practices, develop recommendations for the improvement of the EEU pharmaceutical industry on the basis of using the capabilities of GVCs.

\section{Analysis of the interaction of the EEU countries in pharmaceutical AVC (on the example of Russia and Republic of Kazakhstan (RK): results and discussion}

We obtained the following results at stage 1 . First result - in the pharmaceuticals production: starting in 2015, when the volume of produced pharmaceutical products in the EEU countries amounted to $\$ 5372.3 \mathrm{mln}$., the volume of production grew steadily and pharmaceutical products worth $\$ 9243$ million were produced in the Union in 2018. Growth in comparison with 2014 amounted to $36 \%$ and this gives the experts reason to state that the pharmaceutical industry in the EEU shows stable growth (on average by $2-4 \%$ per year). The Eurasian economic commission considers this sector a priority for the industrial cooperation. Among countries in terms of volume, Russia is the leader $90.8 \%$ of the total amount of produced products, followed by Belarus (6.5\%), Kazakhstan (2.4\%), Armenia $(0.2 \%)[6,8,9]$.

Second result - in sales: the pharmaceutical market of the EEU countries in aggregate is one of the most dynamic and fastest growing world markets, the cumulative growth of which before the pandemic was about $10 \%$. Among the member states, the leaders with an average annual increase in volumes before the pandemic over $10 \%$ are RK and Russia. The main partners of the Union countries are the USA, Germany, Switzerland, and France (for example, in RK, the volume of foreign trade with the EU countries is 65.1\%) [6,9]. Another feature is that the EEU pharma market is import-dependent: the main final products and its components are produced mainly abroad (local pharmaceuticals in the countries, except Russia, provide their own market by less than $50 \%$ (in Belarus - 7\%, in RK - 2\%) [8].

Despite the fact that the issues of creating a common market and integration within the EEU industry markets have been worked out since 2014, the volume of intraregional trade in pharmaceutical products is still minimal (Fig. 1).

We see in diagram that the volume of pharmaceuticals intraregional trade of the EEU member states is increasing. But its share in the total international trade with all countries is very low. We can calculate it not more than $4,5 \%$. The reason is huge import (final products and components) from European countries.

Third result - recent changes in the business environment, including institutional and legal, indicate the possibility of increasing the volume of mutual trade. Firstly, there are improvements in terms of the formation of a common information base, taking into account the peculiarities of the digital economy, harmonization of requirements for the quality of products and the introduction of quality management systems based on the unified international GMP standard, the adoption of an Agreement on common principles and rules of circulation of medicinal products in EEU [8]. Secondly, the activities of the EEU Association of Pharmaceutical Manufacturers are also aimed at strengthening the single pharmaceutical market of the Eurasian Economic Union, the purpose of which is not only to strength the domestic pharmaceutical industry competitiveness but intellectual 
interaction also [10]. For this, the member states of the Association have major centers of competence, including research laboratories, their own know-how and other intellectual property in the development of pharmaceutical technologies, especially in Russia [10]. Thirdly, in the future, in 2021, it is planned to introduce product labeling to track their movement by regulatory authorities, which will make the passage of pharmaceuticals between borders more free and transparent [8]. The COVID-19 pandemic has made its own changes in developing new mechanisms, for example, the EEU has intensified the transition to distance format for pharmaceuticals production inspection, including EU framework.
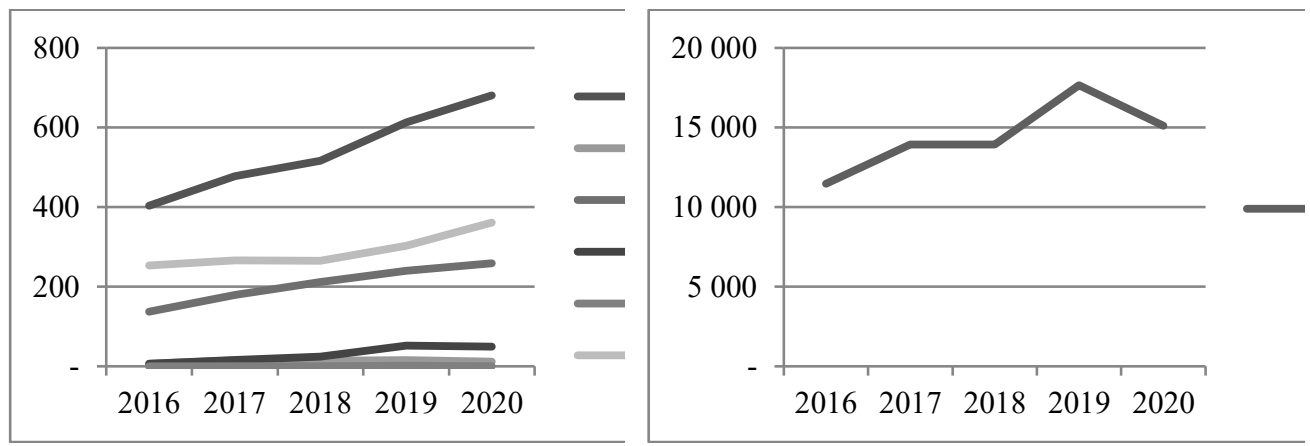

Fig. 1. Volumes of internal and external pharmaceuticals trade of the EEU member states 2016-2020, million dollars [9]

To analyze at stage 2 the pharmaceutical industry and the domestic pharmaceutical market of one of the EEU countries, the RK was selected as one of the EEU leaders. Obtained in step 2.1 results are summarized in Table 1.

Table 1. Comparative characteristics of the pharmaceutical industry and market development in Kazakhstan [6, 8, 9, 11, 12]

\begin{tabular}{|c|c|c|}
\hline Indicator & Pre-pandemic level and trends & Pandemic level and trends \\
\hline $\begin{array}{l}\text { Pharmaceutical } \\
\text { production } \\
\text { volume }\end{array}$ & $\begin{array}{l}\text { Volume of pharmaceutical } \\
\text { production in the period from } 2010 \\
\text { to } 2018 \text { increased fourfold: from } \\
19.9 \text { to } 78.8 \text { bln tenge or } \$ 228.6 \\
\text { mln; for the pre-pandemic }(2019) \\
\text { volume increased by } 18 \% \text { and } \\
\text { amounted to } 92 \text { bln tenge }\end{array}$ & $\begin{array}{c}\text { For eight months of } 2020 \text {, domestic } \\
\text { enterprises, providing a high demand for } \\
\text { pharmaceutical products, achieved an } \\
\text { increase in production by } 34.1 \% \text {, or } 81.5 \\
\text { bln tenge [6]. By the end of } 2020 \text {, the } \\
\text { volume of pharmaceutical production } \\
\text { increased by } 47 \%\end{array}$ \\
\hline $\begin{array}{l}\text { Pharmaceutical } \\
\text { market volume }\end{array}$ & $\begin{array}{c}\text { Market volume has grown steadily } \\
\text { since } 2016 \text { at the end of } 2019 \\
\text { amounted to } \$ 1.6 \text { bln }\end{array}$ & $\begin{array}{l}\text { Market size in } 2020 \text { continued to grow } \\
\text { and amounted to } \$ 1.8 \mathrm{bln}\end{array}$ \\
\hline $\begin{array}{l}\text { Export volume } \\
\text { of } \\
\text { pharmaceutical } \\
\text { products }\end{array}$ & $\begin{array}{l}\text { Exports increased from } \$ 22.3 \mathrm{mln} \\
\text { in } 2016 \text { to } \$ 34.9 \mathrm{mln} \text { in } 2018 . \mathrm{In} \\
2019 \text {, the volume increased by } 69 \% \\
\text { and amounted to } \$ 59 \mathrm{mln}, \$ 19 \mathrm{mln} \\
\text { in four months } 2019\end{array}$ & $\begin{array}{l}\text { Volume of exports after a } 15 \% \text { decrease } \\
\text { in two months and in general for four } \\
\text { months of } 2020 \text { amounted to } \$ 20.4 \mathrm{mln}\end{array}$ \\
\hline $\begin{array}{l}\text { Import volume } \\
\text { of } \\
\text { pharmaceutical } \\
\text { products }\end{array}$ & $\begin{array}{l}\text { Imports increased from } \$ 968 \mathrm{mln} \text { in } \\
2016 \text { to } \$ 1,178 \mathrm{mln} \text { in } 2018 \text { and } \$ \\
1,136 \mathrm{mln} \text { in } 2019 . \text { In four months } \\
2019 \text { amounted to } 395 \mathrm{mln} \text { doll }\end{array}$ & $\begin{array}{c}\text { Imports for four months of } 2020 \\
\text { amounted to } \$ 462.3 \mathrm{mln} \text {, which exceeds } \\
\text { the same indicator for the corresponding } \\
\text { period of the previous year by } 17 \% \text {. }\end{array}$ \\
\hline
\end{tabular}

Analysis of the table data demonstrates growth in all indicators. It is certainly driven by the demand for pharmaceuticals during the pandemic. However, some national peculiarities are noteworthy. Firstly, it is the high import dependence of the RK pharmaceutical market. 
It is confirmed not only by large volumes of imports, but also by a small number of national manufacturers of leading companies [5]. This level of import dependence of the pharmaceutical market is also typical for other EEU countries (for example, 64\% in Belarus, 97\% in Kyrgyzstan), local pharmaceuticals provide their own market for less than half $[5,8]$. However, in a pandemic year, the growth of production volumes in RK, according to the Ministry of Industry and Infrastructure Development, was provided by national enterprises [12].

The next step 2.2 through GVC-analysis of the national pharmaceutical industry will allow to understand how RK managed to create its own pharmaceutical production in such a short time (in 2014 there was not a single national enterprise-leader in RK) [5]. Despite the fact that the "production" stage of GVC has the minimum added value and is not recommended for localization, nevertheless, RK, realizing the importance of the domestic industry, seeks to progress the process of producing its own pharmaceuticals, bringing their level in government orders above 50\% [5].

But having left this decision from import dependence in terms of ready-made pharmaceuticals, the national enterprises of the EEU countries did not leave it in terms of pharmaceutical substances for pharmaceuticals, since purchase them abroad [8]. For example, in RK, leading factories with modern technologies have been built, but they are only engaged in "assembly": imported substances are supplied to the enterprises, where pharmaceuticals, mainly generic are then bottled [8]. Analysis of the structure of imports for the 1st quarter of the pandemic year 2020 confirms this feature: the import of substances in RK amounted to $52.9 \%$. So, it is necessary to create the raw material base in EEU.

Another feature is that production in RK is represented by two modifications: filling imported syringes with imported suspension and filling local syringes with it. For RK, a significant increase in the volume of domestic syringes production should be noted: in the first 5 months of the pandemic 2020, it increased more than 2.5 times and amounted to 64.6 mln pieces compared to the same period in 2019 with a volume of 23 mln units [13]. Organization of this production we consider as a transition to a new stage in pharmaceutical GVC, and the pandemic has accelerated it.

The analysis of economic entities at step 2.3 showed that among the Kazakhstan enterprises that made the largest contribution to the growth of production volumes in the pandemic 2020, experts name the following [12, 13, 14]:

- JV “Abdi İbrahim Global Pharm" LLP: produces more than 70 pharmaceuticals, currently sells its products through distribution networks and exports to countries such as Azerbaijan, Uzbekistan, Tajikistan, Kyrgyzstan, and in the near future it is planned to expand the geography of exports to Russia, Belarus, Turkmenistan, Moldova and Armenia (the company's goal is to obtain a leading position in the export of pharmaceuticals among the CIS countries);

- JSC "Khimfarm": the volume of manufactured products and the export has doubled over the past 2 years, the company's pharmaceutical products are in demand in the markets of Central Asia and the EEU, are exported to Kyrgyzstan, Tajikistan, Turkmenistan, Mongolia and Russia, it is planned to enter the Uzbekistan market, but the central task is to enter the pharmaceutical market of the European Union (by 2023 , it is planned to increase the volume of exports to 16 billion tenge or 2.79 billion rubles);

- $\quad$ "NOBEL Almaty Pharmaceutical Factory": the company is one of the three leading companies in the Kazakhstan market, in the last 2-3 years it has demonstrated a good increase in production and sales; the share of exported products from the total volume of products produced at this enterprise is $25 \%$

These companies operate on the basis of imported components. During the pandemic, the situation was as follows [14]: many suppliers of pharmaceutical substances stopped or 
restricted their work, and prices for the most popular raw materials increased; the world's main suppliers of some substances even imposed export embargoes. The pandemic has demonstrated that the production of pharmaceutical substances of some drugs must be established within the country, because countries can stop production, or close borders. Therefore, Kazakh enterprises plan to establish the production of several pharmaceutical substances on the territory of Kazakhstan.

Experts associate the aforementioned fourfold increase in production volumes in the pharmaceutical industry of the Kazakhstan in the period from 2010 to 2018 with attracting foreign investment: such large producers as Polpharma (has a share in the authorized capital of JSC "Khimfarm"), Nobel (has a share in the authorized capital of Nobel AFF), Pharmstandard, Kelun and a number of others. Currently, the issue of attracting investments from TNCs among the world's leading pharmaceutical producers Big Pharma - Top 50: Pfizer, Boston Biopharma, Avantgen and Servier is being considered [8]. The analysis demonstrates that almost all of these companies operate as TNCs with a registration outside the EEU: mainly the United States (Pfizer, Boston Biopharma, Avantgen), Turkey (Nobel, Abdi Ibrahim), Poland (Polpharma), China (Kelun). Among EEU countries, only Russia (Pharmstandard) is presented, and if we turn to the Association of Pharmaceutical Manufacturers of the Eurasian Economic Union, in addition to Pharmstandard, there is a Russian full-cycle producer "Biocad" in Kazakhstan (for comparison: In Belarus, 3 out of 5 largest companies have European "citizenship") [5, 10].

The form of interaction between these companies is the localization of the GVC links "secondary packaging" of the finished substance from Russia (investments from Biocad) [15], "production" in the form of a spill of the incoming substance into syringes (investments from Pharmstandard in "Karaganda pharmaceutical complex" [16]), and with the subsequent consumption of pharmaceuticals in Kazakhstan, and not export to nonmember countries, which provides for participation in the GVC.

To enhance the development of the pharmaceutical industry (through the prism of GVCs) Kazakhstan plans [8]:

- On the "raw materials" link - to reduce the rates of import customs duties for raw materials and components; to develop measures of state support in terms of reimbursing the costs of purchasing expensive imported raw materials,

- For the R\&D link - to increase the amount of funding for scientific research; to develop a separate regulatory framework for the development of Kazakhstan laboratories that meet GLP standards, as well as measures of state support in terms of reimbursing the costs of conducting clinical trials of pharmaceuticals.

In our opinion, separately, none of the companies of the EEU countries, except for Russia, will be able to fundamentally finance the formation of pharmaceutical AVC, since their development is associated with a huge volume of R\&D and corresponding investment resources. Therefore, in addition to the already existing AVC from Russian Pharmstandard, a potential phytochain from Kazakhstan's Phytokhimia, we recommend the EEU countries to design the formation of a strategic regional TNC (consortium) in order to concentrate investment resources on R\&D stage on the basis of cooperation and specialization by links of all EEU member states.

\section{Conclusions}

The following features of the EEU countries industry, trade and interaction in pharmaceutical GVCs are identified:

- Despite the pandemic period, the pharmaceutical industry of all EEU countries shows growth, but the volume of intraregional trade in pharmaceuticals compared to the 
total volume of the country's foreign trade is insignificant, which indicates the weak development of the regional VC;

- Russia is the leader among the EEU countries (it accounts for $90.8 \%$ of the total EEU pharmaceutics volume) than Kazakhstan, so they have to accumulate investment and initiate together the R\&D stage generation in regional GVC and than as a final to create the common strategic regional corporation with all EEU countries participation ;

The measures taken in the EEU have improved and are improving the business environment, which allows us to speak about the intensification of interaction and cooperation between the countries members of this integration association.

The Kazakhstan case as a leader of EEU revealed features of its participation in the pharmaceutical GVCs:

- this country interacts with regional VCs in such forms as a share in the authorized capital, localization of "production" and "packaging" stage (Russian companies from the EEU countries are present only), but this cannot be considered as a full-fledged participation in the GVC, because, firstly, there is no export to third countries, secondly, the benefits promised by the participation in GVC in the form of access to new markets are not realized;

- all pharmaceutical products produced from the imported component in the frame of value chains are consumed within the country, but in the case of organizing their export to third countries, participation in the GVCs can be full-fledged;

- $\quad$ RK managed to develop domestic pharmaceutical production by attracting foreign investments in the framework of Turkish ("NOBEL", "Abdilbrahim"), Polish ("Polpharm"), Chinese ("Kelun"), Russian ("Pharmstandart") GVC;

- despite the low level of added value in the "production" stage of GVCs a new modern factories with a large number of jobs were built; despite the high share of foreign investors in the authorized capital of Kazakh companies, the country managed to find a balance between national and supranational interests due to a favorable business environment.

\section{Acknowledgements}

The research has been prepared with the support of the Russian Foundation for Basic Research, the Project № 20-014-00011 "Comparative analysis of the integration of national companies in the GVC: the case of Russia, Belarus, Kazakhstan", within the framework of the state task of the Institute of Economics, Ural Branch of the RAS (2021-2023)

\section{References}

1. V. V. Perskaya, Economic strategies, 5 (2015)

2. O. V. Biryukova, I. A. Manuilov, ENSR, 1(76) (2017)

3. T. Meshkova, E. Moiseichev, Foresight and STI Governance, 1 (2016)

4. Y. M. Kukushkina, International trade and trade policy, 4(8) (2016)

5. P. A. Nalimov, D. Y. Rudenko, Bulletin of the Tyumen State University. Socioeconomic and legal research, 1 (2018)

6. EAEU pharmaceutical industry shows stable growth (2019) https://news.rambler.ru/

7. G. Gereffi, K. Fernandez-Stark, Global Value Chain Analysis: A PRIMER (2016) https://www.researchgate.net/ 
8. A. Ivanilova, The pandemic played into the hands of the pharmaceutical market of Kazakhstan (2020) https://mk-kz.kz/

9. EAEU statistics (2020) http://www.eurasiancommission.org/

10. Association of Pharmaceutical Manufacturers of the EAEU (2020) https://www.gosrf.ru/

11. Statistical Yearbook of Kazakhstan. Key indicators by type of economic activity. Manufacturing of basic pharmaceutical products. Committee on Statistics of the Republic of Kazakhstan (2021) https://stat.gov.kz

12. At the end of 2020, the volume of production in the pharmaceutical industry of the Republic of Kazakhstan increased by 47\% (2021) https://www.trend.az/

13. The volume of production of pharmaceutical products in the Republic of Kazakhstan in January-May 2020 increased by $21.2 \%$ (2021) https://pharm.reviews/

14. Kazakhstan pharmaceutical industry and COVID-19. Impact and forecasts for the future (2020) https://yandex.ru/

15. Biocad (2021) https://biocadglobal.com/

16. Karaganda pharmaceutical complex (2020) http://kphk.kz/ 